\title{
韓国釜山市の土地区画整理地区における住宅の 庭の構成と植栽について
}

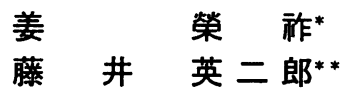

A Consideration of the Composition and the Plantings of the Garden in Urban Readjusted Residential Area of Pusan, Korea

Young-jo KANG

Eijiro FusII

\begin{abstract}
摘要 : 日本の都市住宅との比較を念頭において，韓国釜山市の $6 \supset$ つ住宅地区を対象に，地形や道路，方位等と住宅 の向きや大門の位置との関係を解析した。また，建物と庭の地割との関係や，庭の構成とその植裁との係わりについ て、現地調査をもとに考察した。住宅の向きは，日照を確保するために南向きが多いが，合わせて地形条件す重視す る傾向が見られた。大門は住宅の前面に位置し，その背後になる例は見られなかった。庭の植裁はその平面構成から 二の字型、口の字型、日の字型に大別でき，それらはすべて庭の中央部に広場を碓保する形であった。その植栽構成 は庭を戸外室として形づくるものであり，住宅の内部からの眺めを意図したものではなかった。
\end{abstract}

1.はじめに

居住環境の快適性を確保し維持するためには個人住宅 の庭が大切であるとの指摘がある。 ${ }^{122) 3)}$ しかし，この ような研究は住宅の庭の量的な側面を浮き彫りにしたも のであって, 庭の平面的構成とその配植や施設配置など の質的な側面や，居住者の満足度に及ぼす影響等に関し た研究はまだ少ない。そこで, 筆者らは住宅の庭の質と 居住者の満足度との関係を探るため, 先ず都市住宅の庭 についてその類型的特徵を整理し，その構成原理を把握 する必要があると考えた。

本稿はこうした観点から韓国の釜山市における住宅地 を調查対象として, 都市住宅の庭の構成と植栽の特性を 探ることを目的としている。具体的には，(1)住宅の向き と大門（屋敷囲いに設けられた主な出入口）の位置, (2) 大門から玄関に向けたアプローチと植栽の平面構成との 関係, (3)庭の主要施設物の配置之観賞視点, (4)配植の特 徵等について考察したものである。

ここで調査対象とした 6 地区は, 韓国第 2 の人口を擁 する釜山市の市内加地形の起伏や傾斜の方向, 庭の存 在などを考虑して選んだ（表 1)。いずれむ土地区画整 理事業により計画的に造成された住宅地であり, 自然発 生的な住宅地ではない。区画整理事業の施工期間は，楊 亭 4 洞地区のみ $1961-2$ 年で, その他は1968-72年であ る。しかし, 各宅地における建物や庭の計画は各戸の独 自の判断でつくられたものである。上記の 6 地区は住居

\section{表- 1 対象地の概要}

\begin{tabular}{|c|c|c|c|c|c|c|}
\hline & 量息2洞 & 長符2洞 & 大沜4洞 & 大㴋5洞 & 席安了洞 & 棫亭4洞 \\
\hline 瀼 $\left(\mathrm{m}^{2}\right)$ & $15,495.0$ & $18,247.5$ & $9,769.5$ & $14,297.0$ & $14,659.0$ & $6,815.0$ \\
\hline$+(x)$ & 39.40 & 26.66 & 25.60 & 32.13 & 25.55 & 22.75 \\
\hline 地 $\quad(x)$ & 12.20 & 6.54 & - & 5.21 & 1.07 & - \\
\hline 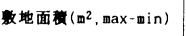 & $800-152$ & $294-88$ & $333-104$ & $1188-98$ & $418-84$ & $288-115$ \\
\hline 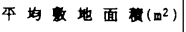 & 344.33 & 175.46 & 171.39 & 190.63 & 148.07 & 139.08 \\
\hline 平 姁 建 其 $(x)$ & 49.75 & 53.37 & 56.82 & 59.72 & 65.33 & 52.30 \\
\hline 建物前面平姁空地相（如） & 7.75 & 3.35 & 3.94 & 4.37 & 3.63 & 3.84 \\
\hline
\end{tabular}

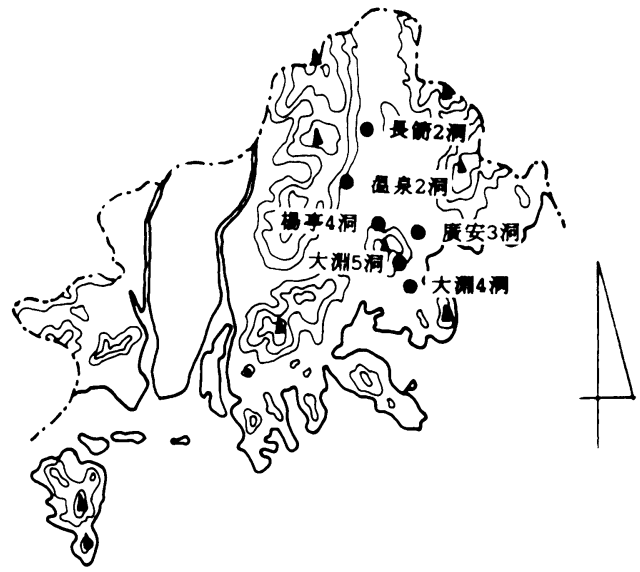

図-1 対象地の位置

“韓国東亞大学校造景学科 **千葉大学園芸学部緑地 - 環境学科 
地域に指定され，法定建蔽率は60\%に定められている。 自然発生的な都市住宅については今後研究を進める予定 である。

\section{2. 研究の方法}

釜山市発行航測図（1989年発行，縮尺 1:1200）を用 いて調查対象地区の土地の起伏や道路パターンを把握し たうえ，各戸ごとに敷地の広さと建蔽率, 建物前面の幅, 道路率を図上計测した。

現地調査の際, 住宅の向きや, 玄関と大門の位置, 植 栽パターン，アプローチの鋪装材料を一戸ごとに記入し た。ここでいう住宅の向きとは主室や居室の面している 方向を指す。また，地図作成時期と調查時期とのずれか ら発生する新築・改築建物の書きむれの部分は調査者が それを補った。

一方, 庭については植栽パターンからみる庭の類型の 代表例について平面図を作成するとともに，庭の使われ 方, 配植および樹種選択の理由，池の観賞地点などを聞 き取った。

調査地区の位置と概要を図 1 と表 2 に示した。

\section{3. 住宅の向きと大門の位置}

\section{(1) 敷地の形状と住宅の向き}

調査対象地区において敷地の形状はほとんど矩形であ る。こうした敷地の上に建てられる住宅の向きは何より 良好な日照が得られるように住宅の部屋割りによって決

\section{表 -2 住宅と大門の方向}

\begin{tabular}{|c|c|c|c|c|c|c|c|c|c|c|c|c|}
\hline & \multicolumn{2}{|c|}{ 温泉2洞 } & \multicolumn{2}{|c|}{ 畏简2洞 } & \multicolumn{2}{|c|}{ 大晸4洞 } & \multicolumn{2}{|c|}{ 大㴋5 洞 } & \multicolumn{2}{|c|}{ 楸安3洞 } & \multicolumn{2}{|c|}{ 盏事4 洞 } \\
\hline & 住宅 & 大門 & 住宅 & 大門 & 住宅 & 大門 & 住宅 & 大阿 & 住毛 & 大門 & 住宅 & 大門 \\
\hline 東 & & 1 & 1 & & & 1 & 6 & 29 & 4 & 3 & & \\
\hline 南東 & 29 & 18 & 35 & 50 & 36 & 15 & & 1 & • 57 & 23 & 2 & 12 \\
\hline 南 & 4 & 2 & & 3 & & 1 & 66 & 15 & 2 & 3 & & \\
\hline 南西 & 4 & 4 & 65 & 9 & 21 & 4 & & & 31 & 26 & 30 & 7 \\
\hline 西 & & 2 & & & & 1 & 3 & 27 & & & & 1 \\
\hline 北西 & & 11 & 1 & 36 & & 20 & & & 3 & 14 & 8 & 19 \\
\hline 北 & & 1 & & & & & & 3 & & & & \\
\hline 北東 & 8 & 6 & 2 & 6 & & 2 & & & 2 & 30 & 9 & 10 \\
\hline 計 & 45 & 45 & 104 & 104 & 57 & 57 & 75 & 75 & 99 & 99 & 49 & 49 \\
\hline
\end{tabular}

まるようである。つまり, なるべく多くの部屋を日照の 良い南側に配置するため, 建物の形状は南に面して長い 形が好まれる。“南向きの家に住むためには三代が積善 すべき。”との諺もある。しかし，敷地の形状によって 住宅が東または西に向く場合むある。

住宅の向きと大門の位置を示した図 2 をみると，200 $\mathrm{m}^{2}$ 以下の小規模住宅の場合, 東西方向に長い敷地であれ ば，敷地の形状に従って東西方向に長い住宅を建てる。 こうした住宅では居室と主室は南側に配置され，台所や トイレ等は北側になる。つまり，南向きの住宅になる。

南北方向に長い敷地の場合, 前述したのと同様に敷地 の形状に従って南北に長い住宅が建てられ，居室や主室

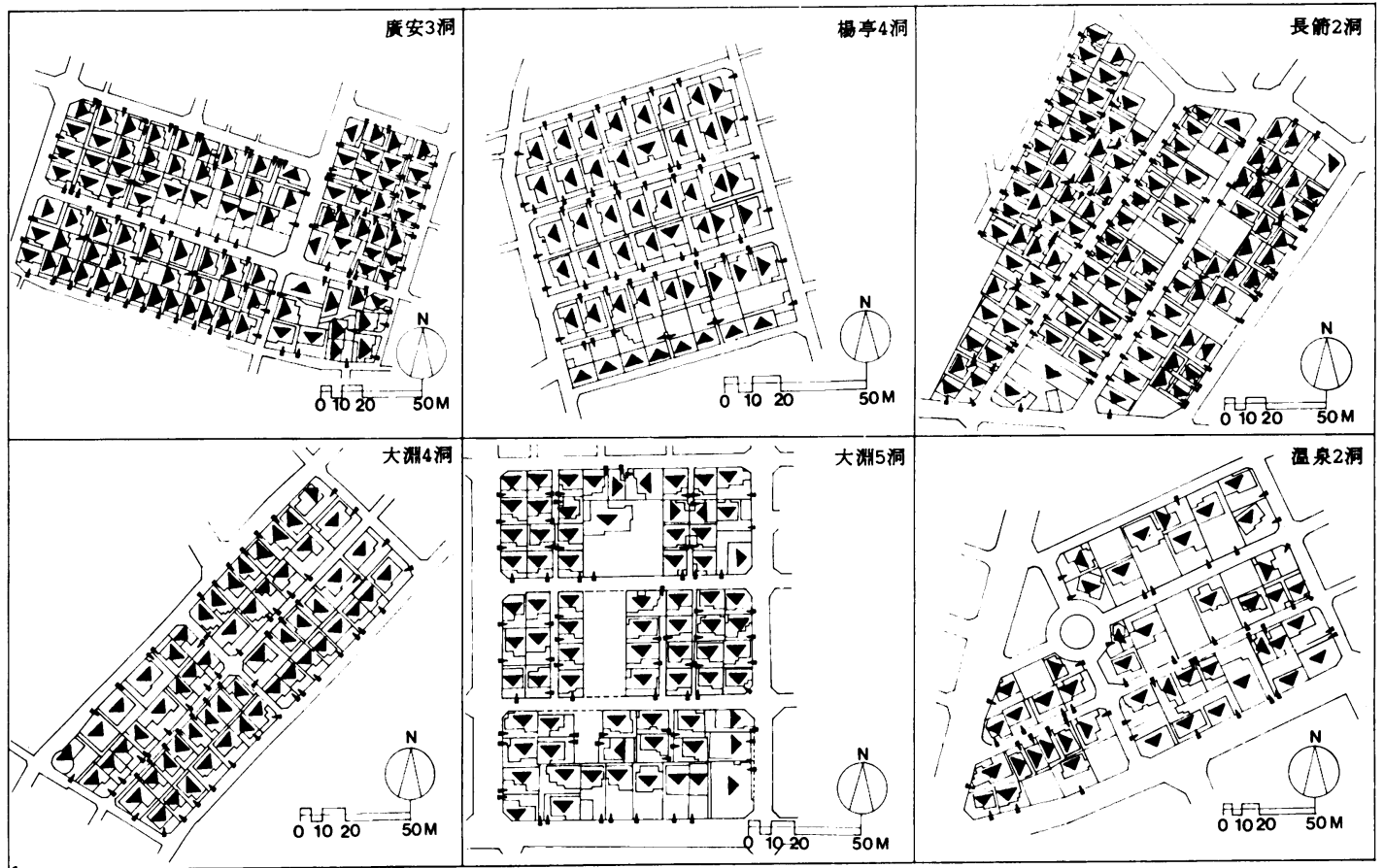

図-2 住宅の向きと大門の位置 


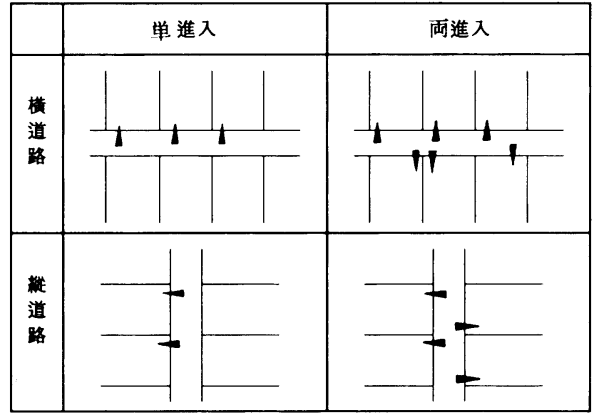

図ー3 道路と住宅への進入形態

は東側または南側に面した場所に配置されることになっ て，東向きの住宅になることが多い。

即ち, 調査地区では農村住宅のように地形の細かい变 化に敏感に対応する形で住宅の向きが決まる(1)5)のでは なく, 地形が南北, あるいは東西方向に傾いている場合 でむ敷地を平らに整地した後, 住宅を建てるから, 地形 が直接的に住宅の向きを左右する要因になるとは考えら れない。

(2) 大門の方位之位置

図 2 に各住宅における大門の位置を示した。住宅と道 路との出入りは実用性を重視して道路から最短距離にな るように設けられている。したがって, 地区内の主要道 路に面した住宅はその主要道路に向けて大門を開くこと になる。図 3 のように, 道路之住宅の向き, 大門の位置 の関係は, 住宅の正面ないし背面に道路が位置する横道 路型と，それが側面に位置する縦道路型に区分でき，ま た道路の両側に大門がみられる両進入型と，それが一方 のみに見られる単進入型とに区分できる。

温泉 2 洞のように東西方向の横道路に面した住宅は南 からの単進入型であり, 大淵 4 洞は南北両方向から進入 するよう大門が付けられる。しかし, 同じく東西方向の横 道路である大淵 5 洞は前述の大淵 4 洞のように南北両進 入型ではなく南側単進入型になっている。大淵 5 洞は街 区の大きさが大淵 4 洞より大きい上, 敷地割りが細分割 されたため街区内に敷地が 4 列になり，主道路に面しな い奥にある住宅の出入りのために袋小路が作られている。

こうした街区内の住宅における大門の付け方は次のよ うである。南側の主道路に面した住宅は南向きに付ける。 また，奥にある住宅は袋小路に沿って大門を付けるから， 向きは東あるいは西向きになっている。そして, 北側の 主道路と袋小路に面した住宅であ北側の主道路ではなく, 袋小路に面して付けることから大門の向きは同じく東あ るいは西向きになる。以上のような結果からみると，大 門の位置として北側は避けられるようである。

大門の位置は多くの場合, 住宅の背後になることはな く正面方向に付ける。図 2 の温泉 2 洞の場合は住宅の裹
手に大門を付けるむのあみられるが，多くの場合，北側 の道路に面して大門を北側にする場合です，住宅の向き を東側あるいは西側にして大門を住宅より前面になるよ うにしている。これは住宅の裏手に道路がある場合，そ こに大門を設ける日本の住宅とは大きく異なる点である。

\section{4. 敷地の形状と囲い}

調查地区の敷地形状は矩形であるため, 屋敷囲いむ敷 地の形に従って矩形の平面形をなしている。

囲いの材料としてはブロックが多く, 生垣, 竹垣, 㭗 などの視線透過性の高い囲いは全く見られない。さらに, その高さは $1.8 \mathrm{~m}$ 以上のものが多く, 敷地が傾斜地に位 置する場合には石積みで敷地を平らにし，その上に囲い を設けているため，道路からの視線を強く遮っており， 通行人には強い閉鎖感を与える敷地囲いである。これは 視線透過性が高く，しかもその高さも視線高前後（高さ 1.5 1.6m）の屋敷囲いが多い日本の都市住宅と対照的 である。一方, 住宅内部からは道路側で感じるほどの閉 鎖感はない。住宅の床面は敷地面より0.8〜 1.0m高くなっ ているため，住宅からの眺めはむしろ開放的である。

\section{5. 庭の構成と植栽の平面パターン}

(1) アプローチの形態

大門から玄関に至るアプローチの形態は図4のように 大きく一字型, クランク型, 銁型, コの字型に分けられる。

一字型は大門から玄関にほぼ一直線に進入するもので 屋敷の横手に大門が位置する住宅でみられる。調査対象 地では一番少ない。

次は建物の横手に付けられた大門から一直線に進入し， 玄関に入る際屈折する銁型がある。これは一字型と同様 に屋敷の横手に大門が位置する住宅で多くみられる。

コの字型は主に大門が住宅の裏手にあって表に玄関が ある屋敷でみられる形態で，大門から玄関を通して住宅 内部に至るアプローチがコの字のようなものである。こ れは, 住宅の向きは南向きであるのに, 大門は住宅の裹 手の北側に付けてある住宅で多くみられる。

一番多いのがクランク型で，大門から玄関に至るアプ ローチが一回屈折するものである。建物の裏手に大門が 付けられる住宅で著しくみられる。李朝時代洪萬選が著 したとされる『山林經濟』の造門雑法には “大門と中門 は同じ線上に置かないのがよい" ${ }^{6}$ との考え方があり， 上述の大門と玄関との位置関係はこの考えを受けつぐと ともに, 一直線のアプローチによる動線の単調さを避け る意図も作用しているものと見られる

アプローチには自然石や平板の飛石があるが，建物前 面の幅が狭い住宅ではモルタル張りになっているところ が多い。

(2) 植栽パターン 


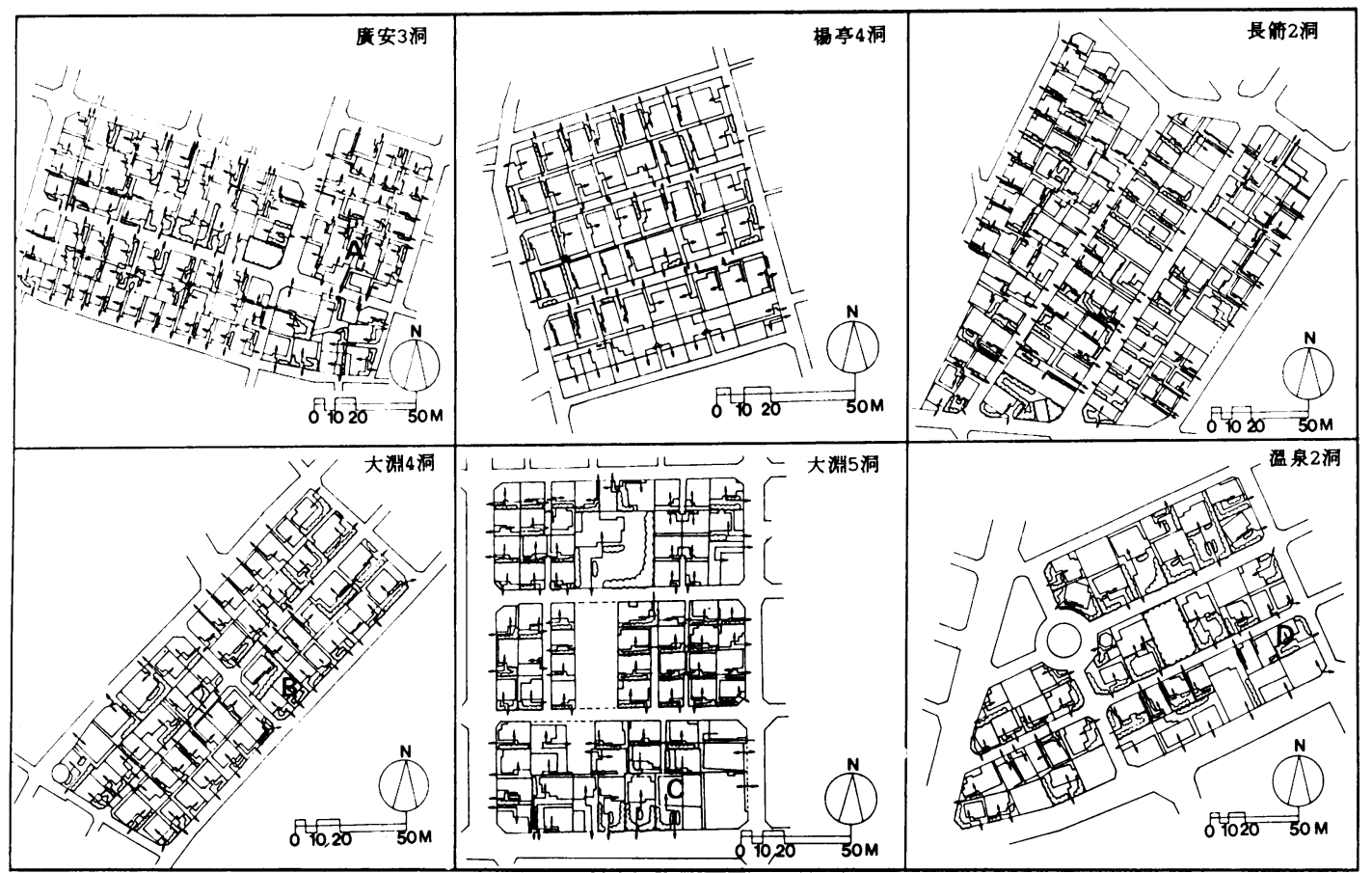

図ー4 アプローチと植栽の現況（A〜Dは植栽パターンの例示対象）

庭において植栽は, その平面構成から図 5 のようにい くつかのタイプに分けられる。

そのひとつは, 大門から玄関に至るアプローチが庭の 大半を占めるもので, 植栽はアプローチの片側, あるい は両側に沿った形で配置される。前者は塀側のみ高木が 列植されるもので, 植栽の平面パターンとしては“一字 型”之“L字型”がある。後者は, 建物側にも低木また は地被が植えられるものであり，これは“二字型”之 “U字型”構成ということができる。

図6に一字型の庭を示した。この図にみる植栽地は石 積みで直線的に縁取られ, モルタル張りのアプローチの 路面より $50 \mathrm{~cm}$ ぼ高くなっている。下木はほとんどない か, あっても単純な構成になっている。

図 7 に二字型の庭を示した。この“二字型”の庭は小 規模な敷地において建物前面の空地の幅が $3 \mathrm{~m} \sim 4 \mathrm{~m}$ 以 下で, アプローチがモルタル張りの住宅でよくみられる。 次のパターンは大門を開けて家に入ると庭の周辺部を 囲うように塀側に石積みによって植栽地盤をつくり，そ こに高木と低木を植え込んでいるもので，アプローチの 機能と同時に後述するように戸外室としての機能も合わ せて持つ庭である。植栽地の平面パターンは“口字型” の構成になり, 植栽は住宅の前面に配置された居室と部 屋の前面にも及ぶことになる。

図 8 は口字型庭の代表例を示した。居室前面の高木植 栽は庭あるいは隣家から建物内への視線を遮断すること
を目的にしていると思われ，居室内から庭を眺める意識 は感じられない。すなわち，庭を眺める視点場としては 居室と居室の前のテラス, 庭の中央部が考えられるので あるが, 部屋の内からは空の高さが $1.0 \mathrm{~m} \sim 1.2 \mathrm{~m}$ と高い ため座ったままでは庭を観賞することはできないのであ る。また，テラスの両側に位置する部屋についてもそれ らの壳は高さが1.0m〜1.2mであり，しかもその高さか らして部屋の中に座って庭を眺めることはできない。し たがって, その空下の植栽は欧米住宅に見られる腰植 (foundation planting) と類縁の植栽と言ってよいも のであろう。

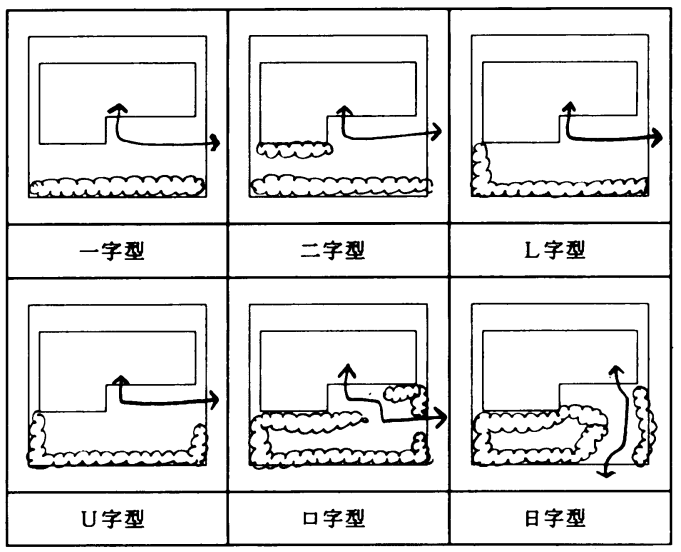

図ー 5 庭の植栽パターンの分類 
一方, 庭の中央部には芝生が張られ，それとその周包 の植栽によって戸外室 (outdoor room) とも呼びう る空間が形づくられている。したがって，建物の内と外 とは明確に区分されており，庭の植栽はそうした空間利 用のあり方をはっきりと物語っている。

つぎのタイプは, 図 9 にみるように, 敷地が傾斜地に 位置しているため, 大門から階段によって一旦庭のレべ ルに上がり，そこから玄関に向かうアプローチの住宅で 見られるもので, 前庭と主庭が空間的に分離されていて 植栽地の平面構成は “日の字型” のタイプである。この タイプでは自然石を積み上げて敷地を平らにしているた め, 道路と同じ高さにある大門は庭の面より低い位置に なる。石積みは大門を開ける場合に邪魔にならないほど にして，平坦な庭面をできるだけ広く取る形になってい る。したがって，大門を入ると高い石積みが目の前にあ り，強い閉鎖感が感じられるが，階段を登るにしたがっ て開放的な庭が展開する。

平坦部の庭の植栽は前述のパターンと同様, その平面 構成は口の字型である。

\section{6. 池の形態亡配植傾向}

(1) 池の観賞視点

池の位置は, 建物に付いている場合と塀際の植栽地に 付いている場合とがある。図 8 は池が塀側の植栽地に,

図 9 は建物に付いている例である。どちらが主な傾向で あるとは言いがたい。

図 9 の場合, 池に面したテラスには欄干があることか ら, 池を眺める視点が室内にないことは明らかである。 池を観賞する視点は, この場合テラスにあり, そこは庭 全体を俯観する地点であある。この池の観賞地点として は庭からの視点の可能性むあるが，そうした視線やアプ ローチを遮る位置に植栽されていることから，ここでは そうした視点は考えられない。

この池際の植栽は, 図 8 之同様芝生の広庭を囲い, その 空間を戸外室とする要素であると同時に, テラスから俯 観して眺める際の水景を構成する要素であある。したがっ て,この庭の構成もまた図 8 と同様, 室内の空間とは明 確に区分された形になっていると言ってよいであろう。

池の形態はほぼ方形であるが, 整形ではなく角が丸く なっている。護岸としては主に自然石を積み上げた石積 み護岸が多い。

\section{（2）配植傾向}

庭において植栽は主に庭の周匄部である塀や建物沿い に見られ，中央部を芝生にしているものが多くみられる。 植栽は, その地盤を石積みなどで縁取りし, 地面より少 し高くして植えられることが多い。

植栽地は敷地の形状に従って矩形ではあるが, 整形で はなく, 角の部分が曲折している。

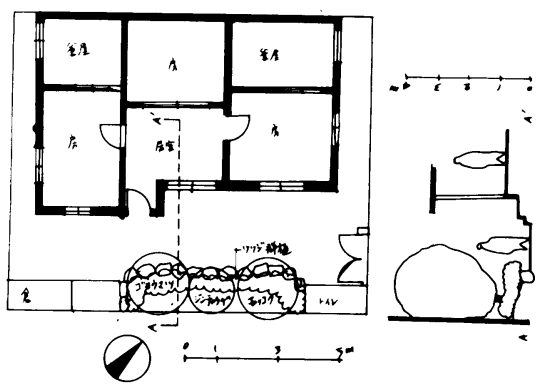

図-6 一字型の庭の例（図4のA）
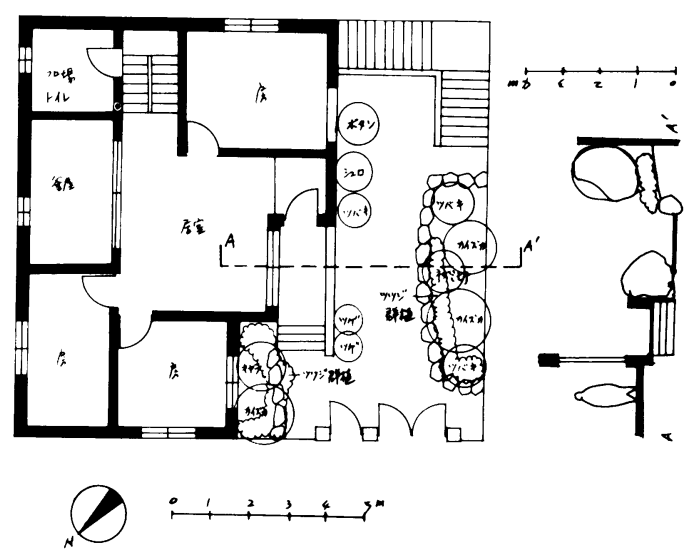

図-7 二字型の庭の例（図4のB）

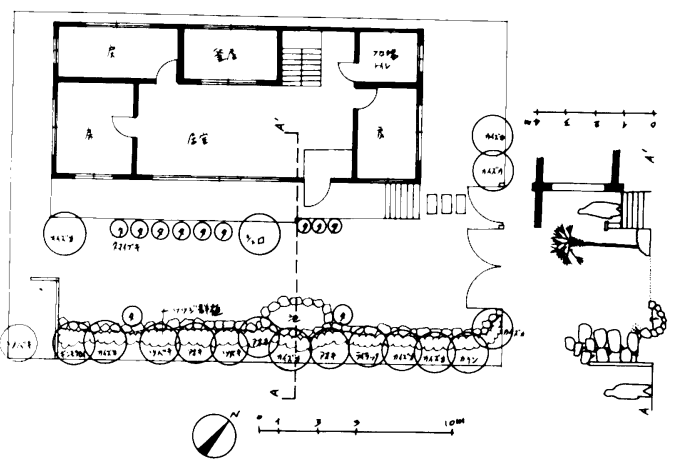

図-8 口字型の庭の例（図4のD） （池が堀側の植栽地に付いているケース）

(3) 樹種

調査地区の場合, 植栽のパターンは違っても植栽樹種 は似ており,よく使われる樹種はカイズカイブキ, シュ ロ, ヤブッバキ, ヒマラヤシーダ, カリン, カキノキな どである。また，これらの樹形については韓国では無剪 定が基本であり，このことはこれらの樹木が大きく生長 した場合む同様であるが，調査地区ではカイズカイブキ, ヒマラヤシーダに限っては段作りがみられた。こうした 仕立木は, 特に日本に隣接した釜山周辺に多いことから 
仕立木が多くみられる日本との地理的連続性を示すすの と言えよう。

樹種別にみた場合, その植栽位置で特徵的な点はシュ 口が決って玄関付近に植えられることである。また，カ イズカイブキは段作りにして塀沿いに植えられる。さら に, 大門の近くにマッを植え, 門冠りにしているところ あみられ，この配植には上述の仕立木と同様，日本との 類似性が指摘できる。下木では, 石積みの隙間にッッジ を植えこむ植栽手法が程度の差こそあれ，どの庭にもみ られた。

\section{7. おわりに}

韓国金山市において区画整理された計画的住宅地の道 路様態ならびに敷地形状と大門の位置や住宅の向きとの 関係，またその住宅の庭の構成とその植栽について考察 を進めてきた。

大門の位置は実用性を重視して道路に近いところに付 けられるが，北側は避けられるようである。また住宅の 向きは敷地の形状に応じて日照のよい南あるいは東方向 を選んでいるが，大門は必ず住宅の前面に設けられる。 大門から玄関を通して住宅の内に入るアプローチは大 きく一字型, クランク型, 銁型, コの字型に分けられる が，いずれも玄関と大門が一直線上にならないようにし ている。これは,『山林經濟』の造門雑法にみる“大門 と中門は同じ線上に置かないのがよい”との考え方を受 けついでいるとともにアプローチに変化をもたらす意図 とみられる。

庭の植栽パターンは一字型, 二字型, L字型, U字型, 口字型，日字型に分けられるが，いずれも塀や建物側に 植栽され, 庭の周辺を植栽で囲う戸外室的な構成になっ ている。大門と玄関が必ず住宅の表側に設けられるため, 建物前面の幅が狭い住宅においては庭空間として修景さ れるべき空間がアプローチとして使われるから，植栽は 建物と塀側に限られて単純な構成になる。また, 比較的建 物前面の幅に余裕がある住宅では庭空間がアプローチの 他, 物千しや活動的レクリエーション等に使われるから,
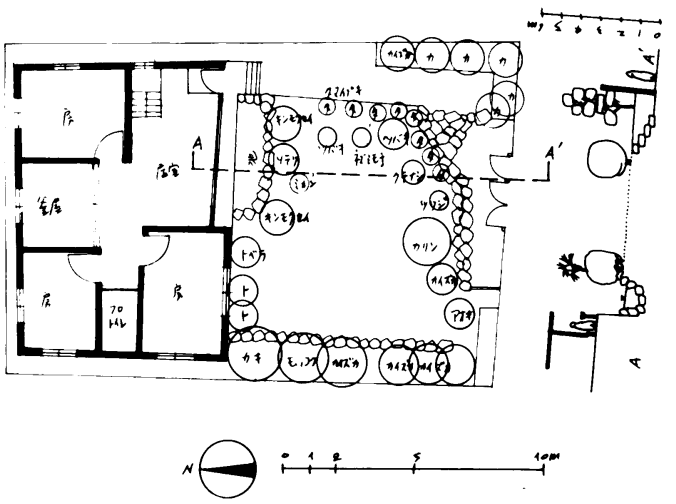

図-9 日字型の庭の例

（池がテラスに付いているケース : 図4のC）

その中央部は農村の庭と同じょうに広庭になっている。 庭の植栽には建物内から眺める形の構成は見られない。 すなわち, 建物の内と外の空間が明確に区分される構成 になっている。

この研究は, 文部省科学研究費 (国際学術調查 課題番 号 : 63041029）の補助を受けて進めたものである。

\section{参考・引用文献}

1) みどりの基準研究開発協議会（1978）：みどりの基 準, 宮崎県

2 ) 平野㑆三 (1983): 都市環境と緑化率に関する計画 論的研究, 緑地学研究 7

3) 姜 榮袮 (1989): 居住地域の緑地環境評価之緑地 の種類に関する研究, 研究報告12(2), 東亞大学環 境問題研究所

4 ）藤井英二郎（1990）: 日本と韓国における庭園を中 心とした緑地の比較文化的研究, 文部省科学研究費 国際学術調查研究成果報告書, 56-68

5 ）李 基徹・金 承煥・藤井英二郎・系賀 黎 (1990) : 韓国・清道地域における農村集落の自然立地と屋 敷配置, 造雑53(5), 395-400

6 ）申 榮勳 (1983)：韓国の住まい, 悦話堂, 380

Summary : We investigated the direction of house, the locations of gate and front entrance, the formation of approach to an entrance, the location of pond, and the plantings of a garden in six readjusted residential areas to analyze the composition and plantings of the garden of the urban residences in Pusan, Korea. The residents have a preferance for a house facing south or east south, however the direction of house set due to the form of house site. The gate is mostly located in front of house. The formation of approach to an entrance are divided into several types, and the gate and the front entrance do not locate on the straight line. Then, we divided the plantings in a garden into several types and analyzed the characteristics of plantings. The plantings surround a front yard and make an outdoor room in the center, and the outdoor space and the indoor space are clearly seperated. 